\title{
Media Internet dan Peta Konsep Untuk Meningkatkan Kemampuan Menulis Teks Eksposisi
}

\author{
Rahayu Pujiastuti, Nurhayati \\ Universitas PGRI Adi Buana Surabaya, SMK Negeri 6 Surabaya \\ rahayu_pujiastuti@unipasby.ac.id, nur19650314@gmail.com
}

DOI: $\underline{\text { http://dx.doi.org/10.32528/bb.v5i1.2773 }}$

Diterima: 13-12-2019

Diterbitkan: 28-02-2020

\begin{abstract}
ABSTRAK
Peserta didik kelas X Jurusan Boga 3 (X-JB3) SMK Negeri 6 Surabaya mengalami tiga permasalahan pada pembelajaran menyusun teks eksposisi, yaitu kesulitan (1) menemukan ide; (2) mengatur urutan peristiwa; (3) mengembangkan urutan peristiwa menjadi teks eksposisi. Hanya 20 atau $57 \%$ dari 35 peserta didik yang dapat mencapai ketuntasan belajar minimal 70. Berdasarkan hal tersebut, tujuan penelitian ini yaitu meningkatkan kemampuan menulis teks eksposisi para peserta didik di kelas X-JB 3, SMK Negeri 6 Surabaya melalui media internet dan peta konsep. Dalam penelitian ini dilakukan tindakan kelas dalam bentuk siklus. Tahap untuk setiap siklus meliputi (1) perencanaan, (2) tindakan, (3)observasi dan evaluasi, serta (4) refleksi. Subjek penelitian 35 peserta didik. Pengumpulan data menggunakan teknik observasi dan penilaian nontes. Penganalisisan data menggunakan persentase dan deskripsi. Hasil penelitian ini adalah media internet dan peta konsep dapat meningkatkan kemampuan menulis teks eksposisi peserta didik kelas X-JB 3 di SMK Negeri 6 Surabaya. Pada proses pembelajaran terlihat adanya peningkatan aktivitas peserta didik dari $79 \%$ pada siklus 1 menjadi $89 \%$ pada siklus 2. Pada hasil pembelajaran terlihat adanya peningkatan kemampuan menulis teks eksposisi dari $71 \%$ pada siklus 1 menjadi $88 \%$ pada siklus 2. Pada proses maupun hasil belajar kriteria 'baik' pada siklus 1 meningkat menjadi 'sangat baik' pada siklus 2
\end{abstract}

Kata Kunci: media internet; peta konsep; eksposisi

\begin{abstract}
Class X students of Boga 3 (X-JB3) Vocational School 6 Surabaya experienced three problems in learning to arrange exposition texts, namely difficulty (1) finding ideas; (2) set the sequence of events to be developed; (3) developing the sequence of events into exposition text. From 35 students, only 20 or $57 \%$ can reach the minimum learning completeness criteria of 70 . Based on this, this study aims to improve the ability to write exposition text of class X-JB 3 students at SMK Negeri 6 Surabaya through internet media and concept maps. This research is a classroom action research conducted through cycles. Each cycle consists of (1) planning, (2) action, (3) observation and evaluation, and (4)
\end{abstract}


reflection. The research subjects were 35 students. Data collection uses nontest observation and assessment techniques. Analyzing data uses percentages and descriptions. Based on the results of the study concluded that internet media and concept maps can improve the ability to write exposition text students in class X-JB 3 at SMK Negeri 6 Surabaya. Improved learning process can be seen from the activities of students $79 \%$ in cycle 1 to $89 \%$ in cycle 2 . Improvement in learning outcomes can be seen from the ability to write exposition text $71 \%$ in cycle 1 to $88 \%$ in cycle 2 . In both the process and learning outcomes the criteria of 'good' in cycle 1 increases to 'very good' in cycle 2 .

\section{Keywords: internet media; concept maps; exposition}

\section{PENDAHULUAN}

Kurikulum 2013 di SMK mata pelajaran bahasa Indonesia diorientasikan untuk membina para peserta didik agar memiliki pengetahuan dan keterampilan berkomunikasi ketika menempuh pendidikan dan dunia kerja. Menurut Suherli, Suryaman, M., Septiaji, A. dan Istiqomah (2017, hal. iii), guna mencapai kompetensi tersebut, pembelajaran bahasa Indonesia di SMK diarahkan untuk mengembangkan kompetensi berbahasa dan bersastra. Kedua kompetensi tersebut diterapkan melalui empat keterampilan, yaitu mendengarkan, membaca, memirsa, berbicara, dan menulis.

Sebagai salah satu keterampilan berbahasa, keterampilan menulis bertujuan agar peserta didik memiliki pengetahuan tentang teori berbagai teks berikut kaidah-kaidah kebahasaannya. Dengan pengetahuan tersebut, peserta didik dapat menerapkan secara tepat, baik dari aspek struktur, isi, maupun kebahasaan.

Ada banyak jenis teks yang diajarkan dalam keterampilan menulis di kelas $\mathrm{X}$ SMK, antara lain teks laporan hasil observasi, anekdot, cerita rakyat, negosiasi, debat, biografi, puisi, dan eksposisi. Menurut Marahimin (2010, hal. 193), eksposisi berarti menyingkap sesuatu yang tertutup atau tersembunyi dengan cara mengungkapkan suatu pikiran, gagasan, atau pendapat. Maskurun dan Basiran (2019, hal. 33) juga menyatakan bahwa teks eksposisi berisi pendapat, sikap, dan pendirian tentang suatu permasalahan yang dilakukan dengan memaparkan argumen yang berupa data/fakta serta rekomendasi (usulan/saran). Menurut Kosasih (2012, hal. 17), teks eksposisi bertujuan untuk memberikan informasi suatu objek sehingga memperluas pandangan atau pengetahuan pembaca.

Menurut Kemendikbud (2013, hal. 195), untuk membuat teks eksposisi perlu memperhatikan struktur teksnya, meliputi (1) tesis, (2) argumentasi, dan (3) penegasan ulang. Maskurun dan Basiran (2019, hal. 35) menambahkan, kebahasaan teks eksposisi, menggunakan (1) bahasa formal/baku, baik dari kosa kata maupun strukturnya; (2) bahasa denotatif; hindari bahasa kias; (3) suatu fakta atau pendapat umum; tidak menggunakan bahasa yang menonjolkan diri sendiri, misalnya aku atau saya; (4) kalimat berita berbentuk kalimat aktif atau pasif; (5) konjungsi perbandingan, pertentangan, syarat, pengandaian, pilihan, dan penegasan.

Kemampuan menulis teks eksposisi penting untuk dimiliki para peserta didik kelas X-Jurusan Boga (X-JB). Dengan memiliki kemampuan tersebut, para peserta 
didik dapat menjelaskan proses dan prosedur yang terkait dengan boga secara baik dan benar. Misalnya, proses untuk membuat makanan, cara meja untuk menyajikan hidangan, cara menghidangkan, dan sebagainya.

Pada kenyataannya, para peserta didik di kelas X-JB3 SMK Negeri 6 Surabaya tahun pelajaran 2019/2020 mengalami kesulitan ketika harus membuat teks eksposisi. Berdasarkan observasi awal yang dilakukan peneliti dan hasil diskusi dengan pendidik mitra, Dra. Nurhayati pada program penugasan dosen ke sekolah (PDS) diperoleh informasi bahwa kemampuan menulis teks eksposisi masih kurang. Dari 35 hanya 20 peserta didik atau 57\% yang dapat mencapai ketuntasan belajar minimal (KBM) 70. Para peserta didik mengalami kesulitan ketika harus (1) menemukan ide; (2) mengatur urutan peristiwa yang akan dikembangkan; (3) mengembangkan urutan peristiwa menjadi teks eksposisi.

Mencermati fenomena tersebut harus dicari solusi sehingga proses dan hasil pembelajaran bisa maksimal. Solusi yang dirasa tepat, yaitu menerapkan media internet dan peta konsep.

Media internet adalah sarana penyampai pesan pembelajaran melalui internet. Menurut Munir (2009, hal. 149), internet adalah sebuah jaringan besar yang di dalamnya terdapat berbagai jaringan, berhubungan dengan pendidikan maupun riset, serta menghubungkan jutaan komputer di dalam sistem jaringan tersebut. Strauss \& Frost (2014, hal. 23) menyatakan bahwa internet adalah jaringan yang bersifat global dari jaringan interkoneksi. Di dalam internet terdapat jutaan jaringan, baik jaringan pribadi, perusahaan, pemerintah, maupun organisasi. Lebih lanjut, Sidharta (dalam Hendrianto, 2014, hal. 59) mengatakan bahwa sebagai dunia maya atau virtual yang ampuh, internet digunakan untuk sarana dalam bidang pendidikan, bisnis, politik, maupun hiburan. Melalui media internet peserta didik terbantu karena media internet dapat digunakan untuk mengunduh berbagai informasi. Dalam penelitian ini, internet dapat digunakan untukmengatasi kesulitan mencari ide ketika menyusun teks eksposisi.

Ide-ide yang ditemukan dari media internet dikonsepkan melalui peta konsep. Dengan peta konsep, seseorang dimudahkan untuk menempatkan suatu informasi ke dalam otak juga mengambil informasi ke luar dari otak. Lebih lanjut dikatakan, peta konsep memudahkan seseorang untuk mencatat secara kreatif, efektif, dan harfiah sehingga dapat memetakan pikiran dengan tepat (Buzan, 2012, hal. 6).

Buzan (2012, hal. 98) menyatakan bahwa dengan peta konsep, para peserta didik terbantu untuk berpikir secara eksplanasi dan kreatif. Caranya, dengan mendaftar berbagai informasi dan konsep yang ada dalam pikiran secara teratur dan berkaitan. Melalui peta konsep tersebut, masalah kedua dan ketiga, yaitu peserta didik sulit mengatur atau mengorganisasi urutan peristiwa serta sulit untuk menyusun teks eksposisi dapat diatasi.

Penggunaan media internet dan peta konsep juga berdasarkan kajian empiris. Beberapa kajian memberi informasi bahwa media internet dan peta konsep dapat digunakan untuk meningkatkan hasil pembalajaran. Hanya saja, pada beberapa penelitian terdahulu, media internet dan peta konsep masih digunakan dalam pembelajaran yang terpisah atau dikombinasikan dengan media atau metode yang lain. 
Pribadi, B. A. dan Delfy, R pada 2015 melakukan penelitian pada peta konsep bagi para guru untuk program tutorial teknik penulisan artikel ilmiah. Hasilnya, kemampuan menulis artikel para guru meningkat setelah menerapkan peta konsep. Untuk media internet pada pembelajaran bahasa Indonesia dilakukan Utami, S., \& Murniasih, M. pada 2017 menerapkan peta konsep untuk menyusun teks eksplanasi. Hasil penelitian menyimpulkan bahwa peta konsep yang diterapkan dengan bantuan media video peristiwa alam, ternyata, membuat proses pembelajaran menjadi lebih optimal. Selain itu, mampu mengubah sikap, baik spiritual maupun sosial para peserta didik ke arah yang lebih baik, serta mampu meningkatkan hasil belajar menyusun teks eksplanasi dari aspek pengetahuan dan keterampilan. Fatria, F. dan Listari pada 2019 juga menyatakan dengan menerapkan media pembelajaran google drive dapat meningkatkan kemampuan berbahasa Indonesia

Berdasarkan penjelasan tersebut, tiga kesulitan belajar para peserta didik di kelas X-JB3 SMK Negeri 6 Surabaya tahun pelajaran 2019/2020 diatasi melalui tindakan kelas dengan cara menerapkan media internet dan peta konsep. Oleh karena itu, penelitian yang dilakukan ini bertujuan untuk meningkatkan kemampuan menulis teks eksposisi melalui media internet dan peta konsep pada peserta didik yang ada di kelas X-JB3 SMK Negeri 6 Surabaya tahun pelajaran 2019/2020. Indikator keberhasilan peningkatan pembelajaran dilihat pada proses yaitu aktivitas peserta didik juga hasil pembelajaran yaitu hasil penilaian peta konsep dan teks eksposisi.

\section{METODE PENELITIAN}

Penelitian yang dilakukan ini berupa penelitian tindakan kelas. Ada empat tahapan yang digunakan, yaitu perencanaan, pelaksanaan, observasi dan evaluasi, serta refleksi yang dilakukan dalam satu siklus. Informasi pada setiap siklus berguna untuk melakukan siklus selanjutnya. Maksudnya, ketika pada suatu siklus belum diperoleh hasil yang ditetapkan akan dilakukan siklus berikutnya. Kekuatan pada pelaksanaan suatu siklus dipertahankan, sedangkan kelemahan atau kekurangannya diperbaiki pada siklus berikutnya.

Subjek penelitian berjumlah 35 orang. Para peserta didik tersebut pada jenjang kelas X-JB3 di SMK Negeri 6 Surabaya dan sedang menempuh semester gasal tahun pelajaran 2019/2020.

Untuk mengumpulkan data digunakan teknik observasi dan nontes (produk). Instrumen berupa lembar observasi dan rubrik penilaian produk. Penganalisisan data dilakukan dengan cara persentase dan deskripsi.

\section{PEMBAHASAN}

Pada bagian ini disampaikan hasil penelitian, baik proses maupun hasil pembelajaran siklus 1 dan 2 kemudian dilakukan pembahasan. 
Siklus 1

\section{Rencana Tindakan}

Rencana pelaksanaan pembelajaran dibuat oleh peneliti (dosen PDS) dan pendidik mitra. Hal yang direncanakan, yaitu (a) menyusun RPP yang menggunakan model berbasis projek karena dapat memfasilitasi penerapan media internet dan peta konsep dalam pembelajaran menulis teks eksposisi; (b) menyiapkan media gambar dari berbagai peristiwa yang diunduh dari media internet (google) sehingga dapat menjadi sumber ide bagi para peserta didik untuk membuat konsep dan sub-subkonsep teks eksposisi; (c) membuat instrumen berupa lembar observasi untuk melihat aktivitas para peserta didik serta rubrik penilaian produk.

\section{Tindakan}

Tindakan siklus I, terdiri atas dua pertemuan. Pertemuan 1 dilaksanakan pada 13 Agustus 2019 dan pertemuan 2 pada 19 Agustus 2019. Setiap pertemuan dilaksanakan 2 x 45 menit. Peserta didik yang hadir pada pertemuan 1 dan 2 tersebut 35 orang.

Tindakan pada siklus 1 terdiri atas langkah awal, inti, dan akhir. Pertemuan 1 diarahkan pada pembuatan peta konsep, sedangkan pertemuan 2 pada pengembangan peta konsep menjadi teks eksposisi.

Pada pertemuan 1, langkah awal terdiri atas aktivitas (1) mengondisi kelas (salam dan berdoa), (2) menyanyikan lagu nasional karena pelaksanaan pertemuan 1 jam ke-4 s.d. ke-5, sedangkan lagu Indonesia Raya sudah dinyanyikan pada jam ke-1, (3) mempresensi, (4) mengapersepsi, (5) memotivasi, dan (6) memberi acuan.

Pada langkah inti dilakukan aktivitas (1) menyuruh peserta didik mengamati slide dan rangkaian gambar yang diunduh dari media internet, (2) menetapkan tugas, (3) membagi peserta didik dalam beberapa kelompok, (4) meminta peserta didik untuk mengamati gambar lain untuk ditemukan data/informasinya, dieksplorasi, dan dibuat peta konsepnya, (5) memberi kesempatan peserta didik untuk bertanya, (6) memantau peserta didik mendesain projek dan menyusun jadwal, (7) memantau ketika peserta didik mencari informasi, (8) setiap kelompok mendiskusikan hasil pengumpulan data, (9) memantau pengerjaan projek sambil menegaskan dua hal penting untuk membuat peta konsep dengan memerhatikan struktur teks dan kebahasaan, (10) peserta didik mempresentasikan hasil projeknya dengan cara menempelkan peta konsep, (11) peserta didik dibimbing untuk menganalisis dan mengevaluasi peta konsep setiap kelompok kemudian menugasi peserta didik untuk merevisi hasil projeknya.

Langkah akhir meliputi aktivitas (1) memberi penghargaan, (2) melakukan refleksi, dan (3) mengakhiri pembelajaran yang dilakukan dengan mengucap salam.

Pada langkah awal pertemuan 2, juga dilakukan enam aktivitas, mulai dari mengondisi kelas hingga memberi acuan. Karena pembelajaran pada jam ke-1 s.d. ke-2, peserta didik menyanyikan lagu Indonesia Raya. Untuk langkah inti, pelaksanaan projek diarahkan untuk membuat teks eksposisi berdasarkan peta konsep yang dibuat pada pertemuan 1. Langkah akhir juga terdiri atas tiga aktivitas, yaitu memberi penghargaan, refleksi, dan mengakhiri dengan mengucap salam. 


\section{Observasi dan Evaluasi}

Pada siklus 1, observasi dilaksanakan ketika pembelajaran, sedangkan evaluasi setelah pembelajaran.. Berikut ini tabel yang berisi rincian aktivitas peserta didik pada siklus 1 pertemuan 1 dan 2 .

Tabel 1: Hasil Observasi Aktivitas Peserta Didik Siklus I

\begin{tabular}{|c|c|c|c|c|c|c|c|}
\hline \multirow{2}{*}{ Per. } & \multirow{2}{*}{ No. } & \multirow{2}{*}{ Aktivitas Peserta Didik } & \multicolumn{5}{|c|}{ Kemunculan } \\
\hline & & & 1 & 2 & 3 & 4 & 5 \\
\hline \multirow[t]{9}{*}{1} & 1. & $\begin{array}{l}\text { Merespon ketika pendidik membuka } \\
\text { pembelajaran (salam, doa, Indonesia } \\
\text { Raya, presensi, apersepsi) }\end{array}$ & $\begin{array}{l}3 \\
(8 \%)\end{array}$ & $\begin{array}{l}5 \\
(16 \%)\end{array}$ & $\begin{array}{l}10 \\
(28 \%)\end{array}$ & $\begin{array}{l}10 \\
(28 \%)\end{array}$ & $\begin{array}{l}7 \\
(20 \%)\end{array}$ \\
\hline & 2. & $\begin{array}{l}\text { Merespon ketika pendidik melakukan } \\
\text { apersepsi }\end{array}$ & $\begin{array}{l}3 \\
(8 \%)\end{array}$ & $\begin{array}{l}5 \\
(16 \%)\end{array}$ & $\begin{array}{l}10 \\
(28 \%)\end{array}$ & $\begin{array}{l}10 \\
(28 \%)\end{array}$ & $\begin{array}{l}7 \\
(20 \%)\end{array}$ \\
\hline & 3. & $\begin{array}{l}\text { Memerhatikan penjelasan pendidik } \\
\text { ketika memberi tayangan slide dan } \\
\text { gambar }\end{array}$ & $\begin{array}{l}4 \\
(12 \%\end{array}$ & $\begin{array}{l}7 \\
(20 \%)\end{array}$ & $\begin{array}{l}4 \\
(12 \%)\end{array}$ & $\begin{array}{l}10 \\
(28 \%)\end{array}$ & $\begin{array}{l}10 \\
(28 \%)\end{array}$ \\
\hline & 4. & $\begin{array}{l}\text { Berpartisipasi secara aktif ketika } \\
\text { menemukan data/ informasi dan } \\
\text { mengeksplorasi temuan }\end{array}$ & $\begin{array}{l}2 \\
(6 \%)\end{array}$ & $\begin{array}{l}4 \\
(12 \%)\end{array}$ & $\begin{array}{l}10 \\
(28 \%)\end{array}$ & $\begin{array}{l}10 \\
(28 \%)\end{array}$ & $\begin{array}{l}9 \\
(26 \%)\end{array}$ \\
\hline & 5. & $\begin{array}{l}\text { Berpartisipasi secara aktif ketika } \\
\text { mengerjakan projek membuat peta } \\
\text { konsep }\end{array}$ & $\begin{array}{c}5 \\
(16 \%)\end{array}$ & $\begin{array}{l}3 \\
(8 \%)\end{array}$ & $\begin{array}{l}11 \\
(30 \%)\end{array}$ & $\begin{array}{l}11 \\
(30 \%)\end{array}$ & $\begin{array}{l}5 \\
(16 \%)\end{array}$ \\
\hline & 6. & $\begin{array}{l}\text { Berpartisipasi secara aktif dalam } \\
\text { presentasi dan memberi tanggapan }\end{array}$ & $\begin{array}{l}3 \\
(8 \%)\end{array}$ & $\begin{array}{l}10 \\
(28 \%)\end{array}$ & $\begin{array}{l}7 \\
(20 \%)\end{array}$ & $\begin{array}{l}10 \\
(28 \%)\end{array}$ & $\begin{array}{l}5 \\
(16 \%)\end{array}$ \\
\hline & 7. & $\begin{array}{l}\text { Merespon ketika pendidik melakukan } \\
\text { refleksi/penegasan materi } \\
\text { pembelajaran }\end{array}$ & $\begin{array}{l}3 \\
(8 \%)\end{array}$ & $\begin{array}{l}5 \\
(16 \%)\end{array}$ & $\begin{array}{l}10 \\
(28 \%)\end{array}$ & $\begin{array}{l}10 \\
(28 \%)\end{array}$ & $\begin{array}{l}7 \\
(20 \%)\end{array}$ \\
\hline & & Persentase & $\begin{array}{l}23 \\
(9 \%)\end{array}$ & $\begin{array}{l}39 \\
(17 \%)\end{array}$ & $\begin{array}{l}62 \\
(25 \%)\end{array}$ & $\begin{array}{l}71 \\
(29 \%)\end{array}$ & $\begin{array}{l}50 \\
(20 \%)\end{array}$ \\
\hline & & & & & & $74 \%$ & \\
\hline \multirow[t]{8}{*}{2} & 1. & $\begin{array}{l}\text { Merespon ketika pendidik membuka } \\
\text { pembelajaran (salam, doa, Indonesia } \\
\text { Raya, kehadiran, apersepsi) }\end{array}$ & 0 & $\begin{array}{l}3 \\
(8 \%)\end{array}$ & $\begin{array}{l}12 \\
(34,5 \%)\end{array}$ & $\begin{array}{l}12 \\
(34,5 \%)\end{array}$ & $\begin{array}{l}8 \\
(23 \%)\end{array}$ \\
\hline & 2. & $\begin{array}{l}\text { Merespon ketika pendidik melakukan } \\
\text { apersepsi }\end{array}$ & $\begin{array}{l}1 \\
(4 \%)\end{array}$ & $\begin{array}{l}6 \\
(18 \%)\end{array}$ & $\begin{array}{l}11 \\
(30 \%)\end{array}$ & $\begin{array}{l}10 \\
(28 \%)\end{array}$ & $\begin{array}{l}7 \\
(20 \%)\end{array}$ \\
\hline & 3. & $\begin{array}{l}\text { Memerhatikan penjelasan pendidik } \\
\text { ketika memberi tayangan slide dan } \\
\text { gambar }\end{array}$ & $\begin{array}{l}2 \\
(6 \%)\end{array}$ & $\begin{array}{l}4 \\
(12 \%)\end{array}$ & $\begin{array}{l}10 \\
(28 \%)\end{array}$ & $\begin{array}{l}10 \\
(28 \%)\end{array}$ & $\begin{array}{l}9 \\
(26 \%)\end{array}$ \\
\hline & 4. & $\begin{array}{l}\text { Berpartisipasi secara aktif ketika } \\
\text { mengerjakan projek membuat teks } \\
\text { eksposisi berdasarkan peta konsep }\end{array}$ & $\begin{array}{l}2 \\
(6 \%)\end{array}$ & $\begin{array}{l}5 \\
(16 \%)\end{array}$ & $\begin{array}{l}10 \\
(28 \%)\end{array}$ & $\begin{array}{l}10 \\
(28 \%)\end{array}$ & $\begin{array}{l}8 \\
(23 \%)\end{array}$ \\
\hline & 5 & $\begin{array}{l}\text { Berpartisipasi secara aktif dalam } \\
\text { presentasi projek) dan memberi } \\
\text { tanggapan }\end{array}$ & $\begin{array}{l}2 \\
(6 \%)\end{array}$ & $\begin{array}{l}4 \\
(12 \%)\end{array}$ & $\begin{array}{l}10 \\
(28 \%)\end{array}$ & $\begin{array}{l}10 \\
(28 \%)\end{array}$ & $\begin{array}{l}9 \\
(26 \%)\end{array}$ \\
\hline & 6. & $\begin{array}{l}\text { Merespon ketika refleksi/ penegasan } \\
\text { materi pembelajaran }\end{array}$ & 0 & $\begin{array}{l}3 \\
(8 \%)\end{array}$ & $\begin{array}{l}12 \\
(34,5 \%)\end{array}$ & $\begin{array}{l}12 \\
(34,5 \%)\end{array}$ & $\begin{array}{l}8 \\
(23 \%)\end{array}$ \\
\hline & & Persentase & $\begin{array}{l}7 \\
(3 \%) \\
\end{array}$ & $\begin{array}{l}25 \\
(13 \%)\end{array}$ & $\begin{array}{l}65 \\
(31 \%)\end{array}$ & $\begin{array}{l}64 \\
(30 \%)\end{array}$ & $\begin{array}{l}49 \\
(23 \%)\end{array}$ \\
\hline & & & & & & $84 \%$ & \\
\hline
\end{tabular}

Sumber : Data Sekunder diolah (2019)

Berdasarkan hasil observasi siklus 1, peserta didik sudah mulai aktif. Hal tersebut terbukti dari (1) respon ketika pendidik membuka pembelajaran memunyai rerata $80 \%$, 
(2) respon ketika apersepsi memunyai rerata 73\%, (3) perhatian ketika mengamati slide memunyai rerata 75\%, (4) aktif ketika menemukan data memunyai nilai 82\%, (5) aktif ketika mengerjakan projek memunyai rerata 77,5\%, (6) aktif ketika presentasi hasil memunyai rerata $73 \%$, dan (7) respon ketika refleksi memunyai rerata $83 \%$.

Pada pertemuan 1 dan 2 siklus 1, rerata peserta didik yang kurang aktif karena mendapat nilai 'sangat kurang' dan 'kurang' sebanyak 21\%. Rerata peserta didik yang aktif karena mendapat nilai 'cukup', 'baik', dan 'sangat baik' sebanyak $79 \%$.

Hasil belajar diperoleh melalui evaluasi pada peta konsep dan teks eksposisi. Evaluasi menggunakan rubrik penilaian. Selain itu, memperhitungkan ketuntasan belajar minimal (KBM) untuk individual 70, sedangkan ketuntasan belajar klasikal menggunakan kriteria minimal 85\%. Berikut hasil belajar yang diperoleh pada siklus 1 .

Tabel 2: Hasil Belajar Peserta Didik Kelas X-JB3 Siklus I

\begin{tabular}{|c|c|c|c|c|c|}
\hline \multirow[t]{2}{*}{ No. } & \multirow{2}{*}{$\begin{array}{l}\text { Nama Induk } \\
\text { Siswa (NIS) }\end{array}$} & \multicolumn{2}{|c|}{ Aspek yang Dinilai } & \multirow[t]{2}{*}{ Skor } & \multirow[t]{2}{*}{ Ket } \\
\hline & & Peta Konsep & Teks Eksp. & & \\
\hline 1. & $14637 / 270116$ & 85 & 85 & 85 & $\mathrm{~T}$ \\
\hline 2. & $15406 / 405116$ & 65 & 65 & 65 & TT \\
\hline 3. & $15411 / 410116$ & 75 & 75 & 75 & $\mathrm{~T}$ \\
\hline 4. & $15418 / 417116$ & 65 & 65 & 65 & TT \\
\hline 5. & $15419 / 418116$ & 65 & 60 & 62,5 & TT \\
\hline 6. & $15420 / 419116$ & 80 & 75 & 77,5 & $\mathrm{~T}$ \\
\hline 7. & $15421 / 420116$ & 75 & 75 & 75 & $\mathrm{~T}$ \\
\hline 8. & $15422 / 421116$ & 75 & 75 & 75 & $\mathrm{~T}$ \\
\hline 9. & $15423 / 422116$ & 85 & 85 & 85 & $\mathrm{~T}$ \\
\hline 10. & $15424 / 423116$ & 60 & 65 & 62,5 & TT \\
\hline 11. & $15459 / 458116$ & 60 & 65 & 62,5 & TT \\
\hline 12. & $15460 / 459116$ & 75 & 70 & 72,5 & $\mathrm{~T}$ \\
\hline 13. & $15461 / 460116$ & 75 & 75 & 75 & $\mathrm{~T}$ \\
\hline 14. & $15474 / 473116$ & 75 & 75 & 75 & $\mathrm{~T}$ \\
\hline 15. & $15475 / 474116$ & 75 & 75 & 75 & $\mathrm{~T}$ \\
\hline 16. & $15485 / 484116$ & 60 & 65 & 67,5 & TT \\
\hline 17. & $15487 / 486116$ & 75 & 75 & 75 & $\mathrm{~T}$ \\
\hline 18. & $15490 / 489116$ & 75 & 75 & 75 & $\mathrm{~T}$ \\
\hline 19. & $15509 / 508116$ & 75 & 75 & 75 & $\mathrm{~T}$ \\
\hline 20. & $15510 / 509116$ & 60 & 60 & 62,5 & TT \\
\hline 21. & $15526 / 525116$ & 75 & 75 & 75 & $\mathrm{~T}$ \\
\hline 22. & $15527 / 526116$ & 75 & 75 & 75 & $\mathrm{~T}$ \\
\hline 23. & $15534 / 533116$ & 65 & 65 & 65 & TT \\
\hline 24. & $15535 / 534116$ & 75 & 75 & 75 & $\mathrm{~T}$ \\
\hline 25. & $15536 / 536116$ & 75 & 75 & 75 & $\mathrm{~T}$ \\
\hline 26. & $15543 / 542116$ & 75 & 75 & 75 & $\mathrm{~T}$ \\
\hline 27. & $15547 / 546116$ & 60 & 60 & 60 & TT \\
\hline 28. & $15560 / 559116$ & 65 & 70 & 67,5 & TT \\
\hline 29. & $15561 / 560116$ & 70 & 75 & 72,5 & $\mathrm{~T}$ \\
\hline 30. & $15562 / 561116$ & 75 & 75 & 75 & $\mathrm{~T}$ \\
\hline 31. & $15579 / 578116$ & 70 & 75 & 72,5 & $\mathrm{~T}$ \\
\hline 32. & $15580 / 579116$ & 85 & 85 & 85 & $\mathrm{~T}$ \\
\hline 33. & $15581 / 580116$ & 75 & 80 & 77,5 & $\mathrm{~T}$ \\
\hline 34. & $15600 / 599116$ & 70 & 75 & 72,5 & $\mathrm{~T}$ \\
\hline \multirow[t]{3}{*}{35.} & $15601 / 600116$ & 75 & 70 & 72,5 & $\mathrm{~T}$ \\
\hline & Jumlah & 26 & 25 & & 25 \\
\hline & Persentase & & & & $71 \%$ \\
\hline
\end{tabular}

Sumber : Data Sekunder diolah (2019) 
Pada Tabel 2 terlihat ada 26 atau 74\% peserta didik yang dapat membuat peta konsep dengan baik, tetapi ketika mengembangkan menjadi teks eksposisi masih ada 25 atau $71 \%$. Hal tersebut berdampak pada hasil belajar atau kemampuan peserta didik kelas X-JB 3 SMK Negeri 6 Surabaya tahun pelajaran 2019/2020 untuk menulis teks eksposisi. Jumlah rerata nilai peserta didik yang memenuhi KBM 70 hanya 25 orang atau $71 \%$ belum mencapai ketuntasan klasikal

\section{Refleksi}

Dari hasil penelitian tersebut dibuat kriteria aktivitas peserta didik sebagai berikut.

Tabel 3: Kriteria Aktivitas Peserta Didik dan Hasil Belajar Siklus 1

\begin{tabular}{lll}
\hline No. & Uraian & Kriteria \\
\hline 1 & $80 \%-100 \%$ & Sangat Baik \\
\hline 2 & $66 \%-79 \%$ & Baik \\
\hline 3 & $56 \%-65 \%$ & Cukup \\
\hline 4 & $40 \%-55 \%$ & Kurang Baik \\
\hline 5 & $\leq 40 \%$ & Tidak Baik \\
\hline 6 & $10 \%-29 \%$ & Sangat kurang \\
\hline (Arikunto, $2007: 35)$ &
\end{tabular}

Berdasarkan Tabel 3, diperoleh informasi (1) aktivitas peserta didik pada siklus 1 masih mencapai nilai rerata $79 \%$ dengan kriteria 'baik' dan masih ada rerata $21 \%$ yang belum aktif; (2) hasil belajar menulis teks eksposisi masih belum mencapai nilai ketuntasan klasikal karena dari pagu $85 \%$, masih terpenuhi $71 \%$; berarti memunyai kriteria 'baik'.

Hasil refleksi pada siklus 1 memberi informasi perlunya dilakukan siklus 2 untuk meningkatkan proses dan hasil pembelajaran. Pada siklus 2, hal yang baik pada siklus 1 ini akan dipertahankan, sedangkan hal yang lemah atau kurang akan diperbaiki.

\section{Siklus 2}

\section{Rencana Tindakan}

Pada siklus 2, rencana tindakan tetap untuk memfasilitasi peningkatan proses dan hasil pembelajaran, yaitu menyusun RPP dengan menggunakan pembelajaran berbasis projek karena cocok untuk penerapan media internet dan peta konsep. Selanjutnya, membuat media pembelajaran. Media yang digunakan tetap berupa gambar berangkai yang diunduh dari google, tetapi berbeda topik dengan siklus 1. Setelah selesai menyiapkan media, dibuat dua instrumen penelitian, yaitu lembar observasi aktivitas peserta didik, dan rubrik penilaian peta konsep dan penilaian teks eksposisi.

\section{Tindakan}

Tindakan siklus 2 terdiri atas dua pertemuan. Pertemuan 1 dilakukan pada 27 Agustus 2019, jam ke-4 s.d. ke-5 dan pertemuan 2 pada 3 September 2019, jam ke-4 s.d. ke-5. Setiap pertemuan dilaksanakan 2 x 45 menit. Peserta didik pada pertemuan 1 
sebanyak 35 orang, tetapi pada pertemuan 2 hanya 34 orang karena ada 1 peserta didik sakit.

Siklus 2 ini juga melaksanakan tiga langkah pembelajaran, yaitu langkah awal, inti, dan akhir. Pertemuan 1 ini juga diarahkan pada pembuatan peta konsep, sedangkan pertemuan 2 pada pengembangan peta konsep menjadi teks eksposisi.

Pada pertemuan 1, langkah awal yang dilakukan terdiri atas aktivitas (1) mengondisi kelas (salam dan berdoa), (2) menyanyikan nasional karena pembelajaran dilaksanakan pada jam ke-4 s.d. ke-5, (3) mempresensi, (4) mengapersepsi, (5) memotivasi, dan (6) memberi acuan.

Pada langkah inti dilakukan aktivitas (1) menyuruh peserta didik mengamati slide dan rangkaian gambar yang diunduh dari internet (google), (2) menetapkan tugas, (3) membagi peserta didik dalam beberapa kelompok seperti halnya siklus 1, (4) meminta peserta didik mengamati gambar lain untuk menemukan data/informasinya kemudian mengeksplorasi hasil temuannya, dan membuat peta konsepnya, (5) memberi kesempatan peserta didik untuk bertanya tentang hal yang belum dipahami, (6) memantau peserta didik mendesain projek serta menyusun jadwal, (7) memantau ketika peserta didik mencari data/informasi, (8) setiap kelompok mendiskusikan hasil dari kegiatan mengumpulkan data, (9) memantau pengerjaan projek sambil menegaskan dua hal penting bahwa membuat peta konsep dengan memerhatikan struktur teks dan kebahasaan, (10) peserta didik mempresentasikan hasil projeknya dengan cara menempelkan peta konsep, (11) peserta didik dibimbing untuk menganalisis dan mengevaluasi peta konsep; setiap kelompok kemudian memberi kesempatan untuk merevisi.

Langkah akhir meliputi aktivitas pendidik (1) memberi penghargaan, (2) melakukan refleksi/penegasan, dan (3) mengakhiri pembelajaran dengan mengucap salam.

Pada pertemuan 2, dilakukan enam aktivitas pada langkah awal, mulai dari mengondisi kelas hingga memberi acuan. Akan tetapi, untuk menyanyikan lagu Indonesia Raya diganti dengan lagu nasional lain karena pembelajaran dilakukan pada jam ke-4 dan ke-5. Untuk langkah inti, pelaksanaan projek tidak diarahkan untuk membuat peta konsep, tetapi membuat teks eksposisi berdasarkan peta konsep yang dibuat pada pertemuan 1. Langkah akhir juga terdiri atas tiga aktivitas, yaitu memberi penghargaan, refleksi, dan mengakhiri dengan mengucap salam.

\section{Observasi dan Evaluasi}

Observasi pada siklus 2 ini dilaksanakan ketika tindakan dilakukan, sedangkan evaluasi dilaksanakan setelah pembelajaran, yaitu penilaian pada dua produk, yaitu peta konsep dan teks eksposisi. Hasil dari kegiatan observasi dan evaluasi pada siklus 2 pertemuan 1 dan 2 tampak pada tabel berikut. 
Tabel 4: Hasil Observasi Aktivitas Peserta Didik Siklus 2

\begin{tabular}{|c|c|c|c|c|c|c|c|}
\hline \multirow{2}{*}{ Per. } & \multirow{2}{*}{ No. } & \multirow{2}{*}{ Aktivitas Peserta Didik } & \multicolumn{5}{|c|}{ Kemunculan } \\
\hline & & & 1 & 2 & 3 & 4 & 5 \\
\hline \multirow[t]{9}{*}{1} & 1. & $\begin{array}{l}\text { Merespon ketika pendidik membuka } \\
\text { pembelajaran (salam, doa, Indonesia } \\
\text { Raya, presensi, apersepsi) }\end{array}$ & 0 & $\begin{array}{l}3 \\
(8 \%)\end{array}$ & $\begin{array}{l}12 \\
(34,5 \% \\
\end{array}$ & $\begin{array}{l}12 \\
(34,5 \% \\
\end{array}$ & $\begin{array}{l}8 \\
(23 \%)\end{array}$ \\
\hline & 2. & $\begin{array}{l}\text { Merespon ketika pendidik melakukan } \\
\text { apersepsi }\end{array}$ & $\begin{array}{l}2 \\
(6 \%) \\
\end{array}$ & $\begin{array}{l}4 \\
(12 \%) \\
\end{array}$ & $\begin{array}{l}10 \\
(28 \%) \\
\end{array}$ & $\begin{array}{l}10 \\
(28 \%) \\
\end{array}$ & $\begin{array}{l}9 \\
(26 \%) \\
\end{array}$ \\
\hline & 3. & $\begin{array}{l}\text { Memerhatikan penjelasan pendidik } \\
\text { ketika memberi tayangan slide dan } \\
\text { gambar }\end{array}$ & $\begin{array}{l}3 \\
(8 \%)\end{array}$ & $\begin{array}{l}5 \\
(16 \%)\end{array}$ & $\begin{array}{l}7 \\
(20 \%)\end{array}$ & $\begin{array}{l}10 \\
(28 \%)\end{array}$ & $\begin{array}{l}10 \\
(28 \%)\end{array}$ \\
\hline & 4. & $\begin{array}{l}\text { Berpartisipasi secara aktif ketika } \\
\text { menemukan data/ informasi dan } \\
\text { mengeksplorasi temuan }\end{array}$ & $\begin{array}{l}1 \\
(3 \%)\end{array}$ & $\begin{array}{l}3 \\
(8 \%)\end{array}$ & $\begin{array}{l}10 \\
(28 \%)\end{array}$ & $\begin{array}{l}10 \\
(28 \%)\end{array}$ & $\begin{array}{l}11 \\
(30 \%)\end{array}$ \\
\hline & 5. & $\begin{array}{l}\text { Berpartisipasi secara aktif ketika } \\
\text { mengerjakan projek membuat peta } \\
\text { konsep }\end{array}$ & $\begin{array}{l}2 \\
(6 \%)\end{array}$ & $\begin{array}{l}4 \\
(12 \%)\end{array}$ & $\begin{array}{l}10 \\
(28 \%)\end{array}$ & $\begin{array}{l}10 \\
(28 \%)\end{array}$ & $\begin{array}{l}9 \\
(26 \%)\end{array}$ \\
\hline & 6. & $\begin{array}{l}\text { Berpartisipasi secara aktif dalam } \\
\text { presentasi dan memberi tanggapan }\end{array}$ & $\begin{array}{l}2 \\
(6 \%) \\
\end{array}$ & $\begin{array}{l}4 \\
(12 \%) \\
\end{array}$ & $\begin{array}{l}10 \\
(28 \%)\end{array}$ & $\begin{array}{l}10 \\
(28 \%)\end{array}$ & $\begin{array}{l}9 \\
(26 \%)\end{array}$ \\
\hline & 7. & $\begin{array}{l}\text { Merespon ketika pendidik melakukan } \\
\text { refleksi/penegasan materi } \\
\text { pembelajaran }\end{array}$ & $\begin{array}{l}3 \\
(8 \%)\end{array}$ & $\begin{array}{l}5 \\
(16 \%)\end{array}$ & $\begin{array}{l}10 \\
(28 \%)\end{array}$ & $\begin{array}{l}10 \\
(28 \%)\end{array}$ & $\begin{array}{l}7 \\
(20 \%)\end{array}$ \\
\hline & & Persentase & $\begin{array}{l}13 \\
(5 \%)\end{array}$ & $\begin{array}{l}28 \\
(11 \%)\end{array}$ & $\begin{array}{l}69 \\
(28 \%) \\
\end{array}$ & $\begin{array}{l}72 \\
(30 \%)\end{array}$ & $\begin{array}{l}63 \\
(26 \%) \\
\end{array}$ \\
\hline & & & & & & $84 \%$ & \\
\hline \multirow[t]{7}{*}{2} & 1. & $\begin{array}{l}\text { Merespon ketika pendidik membuka } \\
\text { pembelajaran (salam, doa, Indonesia } \\
\text { Raya, kehadiran, apersepsi) }\end{array}$ & 0 & 0 & $\begin{array}{l}12 \\
(35,5 \% \\
\end{array}$ & $\begin{array}{l}12 \\
(35,5 \% \\
\end{array}$ & $\begin{array}{l}10 \\
(29 \%)\end{array}$ \\
\hline & 2. & $\begin{array}{l}\text { Merespon ketika pendidik melakukan } \\
\text { apersepsi }\end{array}$ & 0 & $\begin{array}{l}4 \\
(12 \%) \\
\end{array}$ & $\begin{array}{l}11 \\
(33 \%)\end{array}$ & $\begin{array}{l}10 \\
(29 \%)\end{array}$ & $\begin{array}{l}9 \\
(26 \%) \\
\end{array}$ \\
\hline & 3. & $\begin{array}{l}\text { Memerhatikan penjelasan pendidik } \\
\text { ketika memberi tayangan slide dan } \\
\text { gambar }\end{array}$ & 0 & 0 & $\begin{array}{l}12 \\
(35,5 \% \\
\end{array}$ & $\begin{array}{l}12 \\
(35,5 \% \\
\end{array}$ & $\begin{array}{l}10 \\
(29 \%)\end{array}$ \\
\hline & 4. & $\begin{array}{l}\text { Berpartisipasi secara aktif ketika } \\
\text { mengerjakan projek membuat teks } \\
\text { eksposisi berdasarkan peta konsep }\end{array}$ & 0 & $\begin{array}{l}3 \\
(9 \%)\end{array}$ & $\begin{array}{l}11 \\
(33 \%)\end{array}$ & $\begin{array}{l}10 \\
(29 \%)\end{array}$ & $\begin{array}{l}10 \\
(29 \%)\end{array}$ \\
\hline & 5 & $\begin{array}{l}\text { Berpartisipasi secara aktif dalam } \\
\text { presentasi projek) dan memberi } \\
\text { tanggapan }\end{array}$ & 0 & $\begin{array}{l}3 \\
(9,5 \%)\end{array}$ & $\begin{array}{l}11 \\
(32,5 \% \\
\end{array}$ & $\begin{array}{l}10 \\
(29 \%)\end{array}$ & $\begin{array}{l}10 \\
(29 \%)\end{array}$ \\
\hline & 6. & $\begin{array}{l}\text { Merespon ketika refleksi/ penegasan } \\
\text { materi pembelajaran }\end{array}$ & 0 & $\begin{array}{l}3 \\
(9,5 \%)\end{array}$ & $\begin{array}{l}9 \\
(26 \%)\end{array}$ & $\begin{array}{l}12 \\
(35,5 \% \\
)\end{array}$ & $\begin{array}{l}10 \\
(29 \%)\end{array}$ \\
\hline & & Persentase & 0 & $\begin{array}{l}13 \\
(6 \%)\end{array}$ & $\begin{array}{l}66 \\
(32 \%) \\
\end{array}$ & $\begin{array}{l}66 \\
(32 \%)\end{array}$ & $\begin{array}{l}59 \\
(29 \%) \\
\end{array}$ \\
\hline
\end{tabular}

Sumber : Data Sekunder diolah (2019)

Berdasarkan hasil observasi siklus 2, peserta didik semakin aktif. Hal tersebut terbukti dari peningkatan keaktifan setiap aktivitas, meliputi (1) respon ketika pendidik membuka pembelajaran memunyai rerata 96\%; (2) respon ketika apersepsi memunyai rerata $85 \%$; (3) perhatian ketika mengamati slide memunyai rerata $88 \%$; (4) aktif ketika menemukan data memunyai nilai $86 \%$; (5) aktif ketika mengerjakan projek memunyai rerata $86,5 \%$; (6) aktif ketika presentasi hasil memunyai rerata $86 \%$; (7) respon ketika 
refleksi memunyai rerata 87\%. Pada siklus 2 pertemuan 1 dan 2, rerata peserta didik yang kurang aktif $11 \%$, sedangkan rerata yang aktif sebanyak $89 \%$.

Hasil belajar diperoleh melalui hasil evaluasi dari dua produk, yaitu peta konsep dan menyusun teks eksposisi juga meningkat. Hasil belajar tetap menggunakan kriteria ketuntasan belajar minimal (KBM) untuk individual yaitu 70, sedangkan secara klasikal kriteria minimal $85 \%$.

Tabel 5: Hasil Belajar Peserta Didik Kelas X-JB3 Siklus 2

\begin{tabular}{|c|c|c|c|c|c|}
\hline \multirow{3}{*}{ No. } & \multirow{3}{*}{$\begin{array}{l}\text { Nama Induk Siswa } \\
\text { (NIS) }\end{array}$} & \multicolumn{2}{|c|}{ Aspek yang Dinilai } & \multirow[t]{3}{*}{ Skor } & \multirow[t]{3}{*}{ Ket } \\
\hline & & \multicolumn{2}{|c|}{ Peta $\quad$ Teks } & & \\
\hline & & Konsep & Eksp. & & \\
\hline 1. & $14637 / 270116$ & 85 & 85 & 85 & $\mathrm{~T}$ \\
\hline 2. & $15406 / 405116$ & 75 & 75 & 75 & $\mathrm{~T}$ \\
\hline 3. & $15411 / 410116$ & 80 & 80 & 80 & $\mathrm{~T}$ \\
\hline 4. & $15418 / 417116$ & 65 & 65 & 65 & TT \\
\hline 5. & $15419 / 418116$ & 60 & 65 & 62,5 & $\mathrm{~T}$ \\
\hline 6. & $15420 / 419116$ & 80 & 80 & 80 & $\mathrm{~T}$ \\
\hline 7. & $15421 / 420116$ & 80 & 80 & 80 & $\mathrm{~T}$ \\
\hline 8. & $15422 / 421116$ & 75 & 75 & 75 & $\mathrm{~T}$ \\
\hline 9. & $15423 / 422116$ & 85 & 85 & 85 & $\mathrm{~T}$ \\
\hline 10. & $15424 / 423116$ & 60 & 65 & 62,5 & $\mathrm{TT}$ \\
\hline 11. & $15459 / 458116$ & 60 & 65 & 62,5 & TT \\
\hline 12. & $15460 / 459116$ & 75 & 70 & 72,5 & $\mathrm{~T}$ \\
\hline 13. & $15461 / 460116$ & 80 & 80 & 80 & $\mathrm{~T}$ \\
\hline 14. & $15474 / 473116$ & 85 & 85 & 85 & $\mathrm{~T}$ \\
\hline 15. & $15475 / 474116$ & 75 & 75 & 75 & $\mathrm{~T}$ \\
\hline 16. & $15485 / 484116$ & 70 & 65 & 67,5 & TT \\
\hline 17. & $15487 / 486116$ & 80 & 80 & 80 & $\mathrm{~T}$ \\
\hline 18. & $15490 / 489116$ & 80 & 80 & 80 & $\mathrm{~T}$ \\
\hline 19. & $15509 / 508116$ & 85 & 85 & 85 & $\mathrm{~T}$ \\
\hline 20. & $15510 / 509116$ & 65 & - & - & - \\
\hline 21. & $15526 / 525116$ & 80 & 80 & 80 & $\mathrm{~T}$ \\
\hline 22. & $15527 / 526116$ & 80 & 80 & 80 & $\mathrm{~T}$ \\
\hline 23. & $15534 / 533116$ & 80 & 80 & 80 & $\mathrm{~T}$ \\
\hline 24. & $15535 / 534116$ & 75 & 75 & 75 & $\mathrm{~T}$ \\
\hline 25. & $15536 / 536116$ & 85 & 85 & 85 & $\mathrm{~T}$ \\
\hline 26. & $15543 / 542116$ & 75 & 75 & 75 & $\mathrm{~T}$ \\
\hline 27. & $15547 / 546116$ & 80 & 80 & 80 & $\mathrm{~T}$ \\
\hline 28. & $15560 / 559116$ & 80 & 80 & 80 & $\mathrm{~T}$ \\
\hline 29. & $15561 / 560116$ & 75 & 70 & 72,5 & $\mathrm{~T}$ \\
\hline 30. & $15562 / 561116$ & 75 & 75 & 75 & $\mathrm{~T}$ \\
\hline 31. & $15579 / 578116$ & 70 & 75 & 72,5 & $\mathrm{~T}$ \\
\hline 32. & $15580 / 579116$ & 85 & 85 & 85 & $\mathrm{~T}$ \\
\hline 33. & $15581 / 580116$ & 80 & 80 & 80 & $\mathrm{~T}$ \\
\hline 34. & $15600 / 599116$ & 70 & 65 & 70 & $\mathrm{~T}$ \\
\hline \multirow[t]{4}{*}{35.} & $15601 / 600116$ & 85 & 85 & 85 & $\mathrm{~T}$ \\
\hline & Jumlah & 30 & 31 & & 30 \\
\hline & Persentase & & & & 88 \\
\hline & & & & & $\%$ \\
\hline
\end{tabular}

Sumber : Data Sekunder diolah (2019)

Tabel 5 tersebut memberi informasi bahwa peserta didik yang dapat membuat peta konsep dengan baik sebanyak 30 atau $88 \%$. Ketika pertemuan 2 ada satu peserta 
didik sakit sehingga jumlah peserta didik yang seharusnya sudah mampu mengembangkan 30 menjadi 31 atau 89\%. Bila tetap berdasarkan jumlah 34 orang berarti peserta didik yang belum mampu mengembangkan teks eksposisi juga 30. Hal tesebut memberi informasi bahwa peta konsep mempengaruhi kemampuan untuk mengembangkan teks ekposisi. Berdasarkan jumlah rerata nilai, peserta didik yang memenuhi KBM 70 ada 30 orang atau 88\% dan memunyai kriteria 'sangat baik'. Dengan demikian, hasil belajar telah mencapai ketuntasan klasikal.

\section{Refleksi}

Berdasarkan hasil penelitian siklus 2, secara keseluruhan ada peningkatan pada proses dan hasil belajar. Hal tersebut terlihat dari peningkatan aktivitas peserta didik dan hasil belajar daripada siklus 1 . Pada siklus 2 ini, peserta didik menjadi lebih aktif, lebih antusias, dan lebih dapat bekerja sama. Aktivitas maupun hasil belajar peserta didik pada siklus 2 menggunakan kriteria berikut.

Tabel 6: Kriteria Aktivitas Peserta Didik dan Hasil Belajar Siklus 2

\begin{tabular}{lll}
\hline No. & Uraian & Kriteria \\
\hline 1 & $80 \%-100 \%$ & Sangat Baik \\
\hline 2 & $66 \%-79 \%$ & Baik \\
\hline 3 & $56 \%-65 \%$ & Cukup \\
\hline 4 & $40 \%-55 \%$ & Kurang Baik \\
\hline 5 & $\leq 40 \%$ & Tidak Baik \\
\hline 6 & $10 \%-29 \%$ & Sangat kurang \\
\hline
\end{tabular}

(Arikunto, 2007:35)

Berdasarkan Tabel 6, aktivitas peserta didik memunyai kriteria 'sangat baik' karena mencapai rerata $89 \%$. Keberhasilan pembelajaran yang terlihat dari aktivitas selama proses belajar tersebut memengaruhi hasil belajar menulis teks eksposisi sehingga dapat melebihi ketuntasan klasikal $85 \%$, yaitu $88 \%$.

Hasil refleksi memberi informasi, ternyata, penerapan media internet dan peta konsep dapat meningkatkan kemampuan peserta didik di kelas X-JB3 SMK Negeri 6 Surabaya menulis teks eksposisi. Dalam penelitian yang dilakukan Utami, S., \& Murniasih, M. (2016:59) juga diperoleh hasil bahwa peta konsep dapat meningkatkan prosese dan hasil pembelajaran menyusun teks eksplanasi. Alifah, A. dan Setyaningrum, T.A. (2019:423) juga memeroleh hasil yang sama yaitu adanya peningkatan hasil pada pembelajaran menulis teks berita dengan menggunakan metode karya wisata dan media peta konsep pohon jaringan.

Meskipun belum maksimal, peningkatan kriteria dari belum tuntas secara klasikal pada siklus 1 menjadi tuntas secara klasikal pada siklus 2 ini dianggap telah memberi informasi. Oleh karena itu, penelitian ini dirasa cukup dilaksanakan dua siklus.

Bila hasil pada siklus 1 dan 2 digunakan sebagai dasar untuk melihat peningkatan kemampuan proses dan hasil belajar para peserta didik kelas X-JB3 di SMK Negeri 6 Surabaya diperoleh informasi sebagai berikut. 


\section{Aktivitas Peserta Didik}

Peningkatan aktivitas peserta didik diperoleh dari observasi saat peserta didik mengikuti pembelajaran. Pada siklus 1 pertemuan 1 dan 2 diperoleh hasil $74 \%$ dan $84 \%$. Jadi, rerata aktivitas peserta didik pada siklus 1 sebesar $79 \%$. Hasil siklus 1 tersebut meningkat

pada siklus 2 karena pada pertemuan 1 dan 2 diperoleh hasil $84 \%$ dan 94\%. Jadi, rerata pada siklus 2, yaitu $89 \%$. Berikut ini tabel tentang peningkatan proses pembelajaran yang dilihat berdasarkan aktivitas peserta didik dari siklus 1 ke siklus 2 .

\begin{tabular}{cllll}
\multicolumn{6}{c}{ Tabel 7: Rekapitulasi Aktivitas Peserta Didik } \\
\hline Siklus & Pertemuan & Pertemuan & Rerata & Kriteria \\
& 1 & 2 & & \\
\hline 1 & $74 \%$ & $84 \%$ & $79 \%$ & Baik \\
\hline 2 & $84 \%$ & $94 \%$ & $89 \%$ & $\begin{array}{l}\text { Sangat } \\
\text { Baik }\end{array}$ \\
\hline
\end{tabular}

Sumber : Data Sekunder diolah (2019)

Berdasarkan hasil pertemuan 1 dan 2 kedua siklus diperoleh deskripsi peningkatan aktivitas peserta didik kelas X-JB3 SMK Negeri 6 Surabaya tahun 2019/2020 sebesar 20\%. Peningkatan aktivitas peserta didik siklus 1 ke siklus 2 tampak pada grafik berikut.

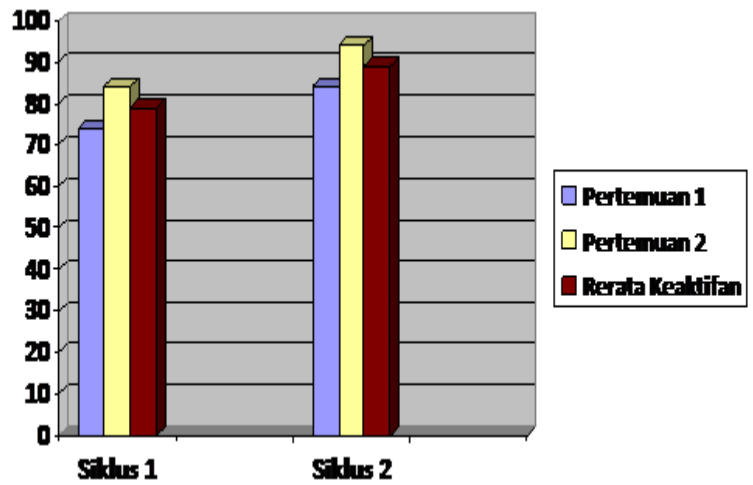

Gambar 1: Peningkatan Aktivitas Peserta Didik dari Siklus 1ke Siklus 2

\section{Hasil Belajar}

Hasil belajar berupa kemampuan menulis teks eksposisi diperoleh dari evaluasi pada peta konsep dan pengembangan peta konsep menjadi teks eksposisi. Berdasarkan hasil evaluasi terlihat adanya peningkatan hasil belajar dari siklus 1 ke siklus 2. Pada siklus 1 diperoleh hasil belajar berupa ketuntasan klasikal 71\%. Hal tersebut berarti hasil belajar pada siklus 1 belum mencapai ketuntasan klasikal. Masih 26 atau 74\% peserta didik yang mampu membuat peta konsep dengan baik dan benar. Hal tersebut berdampak pada pembuatan teks eksposisi yang hanya 25 atau $71 \%$. Ketuntasan belajar klasikal yang diperoleh pada siklus 1 masih $71 \%$ dan memunyai kriteria 'baik'. 
Pada siklus 2 terjadi peningkatan 17\% karena ketuntasan klasikalnya menjadi $88 \%$. Ada 31 orang atau $89 \%$ peserta didik yang mampu membuat peta konsep secara baik dan benar. Hal tersebut cenderung sama dengan jumlah peserta didik yang mampu menyusun teks eksposisi 30 atau $88 \%$. Ketuntasan belajar klasikal pada siklus 2 telah mencapai $88 \%$ dan kriteria 'sangat baik'.

Berdasarkan siklus 1 dan 2 diperoleh informasi peningkatan hasil pada pembelajaran menulis teks eksposisi peserta didik kelas X-JB3 SMK Negeri 6 Surabaya tahun 2019/2020 sebesar 17\%. Berikut ini tabel tentang peningkatan hasil belajar peserta didik.

Tabel 8: Rekapitulasi Hasil Belajar

\begin{tabular}{lllllll}
\hline Siklus & \multicolumn{2}{l}{ Peta Konsep } & \multicolumn{2}{l}{ Teks } & $\begin{array}{l}\text { Ketunt. } \\
\text { Klasikal }\end{array}$ & Kriteria \\
\hline 1 & 26 & $60 \%$ & 31 & $89 \%$ & $71 \%$ & Baik \\
\hline 2 & 30 & $79 \%$ & 30 & $88 \%$ & $88 \%$ & $\begin{array}{l}\text { Sangat } \\
\text { Baik }\end{array}$ \\
\hline
\end{tabular}

Sumber : Data Sekunder diolah (2019)

Bila dirunut dari observasi awal hingga siklus 2 diperoleh informasi peningkatan hasil belajar. Peningkatan kemampuan menyusun teks eksposisi dari 57\% pada observasi awal menjadi $71 \%$ pada siklus 1, yaitu 14\%. Kemampuan tersebut meningkat lagi pada siklus 2; dari $71 \%$ pada siklus 1 meningkat $17 \%$ pada siklus 2 sehingga menjadi $88 \%$. Peningkatan tersebut dapat dilihat pada grafik berikut.

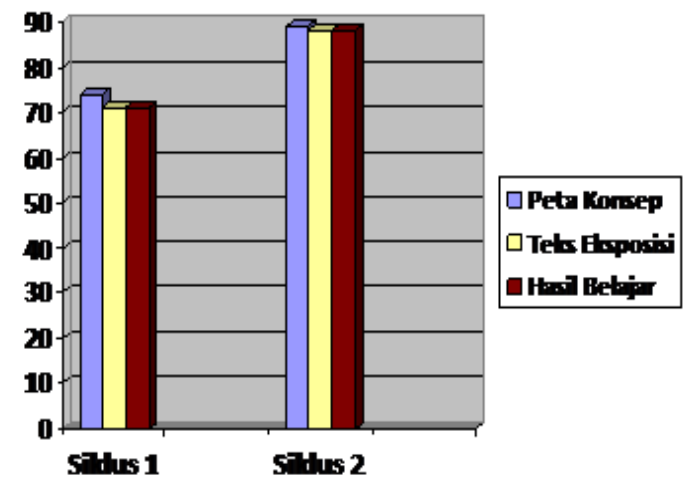

\section{Gambar 2: Peningkatan Hasil Belajar Menulis Teks Eksposisi dari Siklus 1 ke Siklus 2}

\section{SIMPULAN}

Hasil penelitian ini yaitu media internet dan peta konsep dapat meningkatkan kemampuan menulis teks eksposisi peserta didik kelas X-JB 3 di SMK Negeri 6 Surabaya. Hal ini terbukti dari peningkatan proses dan hasil pembelajaran. Untuk peningkatan proses pembelajaran dapat dilihat pada meningkatnya aktivitas peserta didik dari $79 \%$ pada siklus 1 menjadi $89 \%$ pada siklus 2 . Untuk peningkatan hasil pembelajaran juga dapat dilihat dari meningkatnya kemampuan menulis teks eksposisi; 
dari $71 \%$ pada siklus 1 menjadi $88 \%$ pada siklus 2 . Pada proses maupun hasil belajar kriteria 'baik' pada siklus 1 meningkat menjadi ‘sangat baik' pada siklus 2 .

\section{UCAPAN TERIMA KASIH}

Terima kasih kepada (a) Direktorat Pembelajaran, Direktorat Jenderal Pembelajaran dan Kemahasiswaan, Kementerian Riset, Teknologi, dan Pendidikan Tinggi serta (2) Universitas PGRI Adi Buana Surabaya. Kedua institusi telah memberi kesempatan kepada peneliti untuk memeroleh pengalaman berharga melalui program hibah Penugasan Dosen ke Sekolah (PDS). Terima kasih juga kepada SMK Negeri 6 Surabaya, sekolah mitra yang telah memfasilitasi hingga program PDS terselesaikan dengan lancar.

\section{DAFTAR RUJUKAN}

Alifah, A. \& Setyaningrum, T.A. (2019). Media peta konsep pohon jaringan dalam pembelajaran menulis teks berita berbahasa Jawa. Jurnal Sendika. Vol. 1, No. 1, hal. 415-424

Buzan, T. (2012) Buku Pintar Mind Map. Jakarta: Gramedia Pustaka Utama.

Fitria, F. \& Listari. (2017) Penerapan media pembelajaran google drive dalam pembelajaran bahasa Indonesia. Jurnal Penelitian Pendidikan Bahasa dan Sastra, vol. 2, no. 1, April 2017, hal 138-144.

Kementerian Pendidikan dan Kebudayaan. (2013) Bahasa Indonesia Wahana Pengetahuan (Buku Siswa). Jakarta: Kemendikbud RI.

Hendrianto, D. E. (2014) Pembuatan sistem informasi perpustakaan berbasis website pada sekolah menengah pertama 1 Donorejo Kabupaten Pacitan. Indonesian Journal on Networking and Security, vol. 3, no. 24. ISSN: 2302-5700 (Print), 2354-6654 (Online), hal 57-64.

Kosasih, E. (2012). Dasar-dasar Keterampilan Menulis. Bandung: Yrama Widya.

Marahimin, I. (2010). Menulis secara Populer. Jakarta: Dunia Pustaka Jaya.

Maskurun \& Basiran. (2019). Bahasa Indonesia X-A untuk SMK/MAK dan SMA/MA. Yogyakarta: LP2IP.

Munir, (2009). Pembelajaran Jarak Jauh Berbasis Teknologi Informasi dan Komunikasi. Bandung: Alfabeta

Pribadi, B. A., \& Delfy, R. (2015). Implementasi strategi peta konsep (concept mapping) dalam program tutorial teknik penulisan artikel ilmiah bagi guru". Jurnal Pendidikan Universitas Terbuka dan Jarak Jauh. Vol. 16, No. 2. ISSN e-ISSN 2442-2266, 1411-304X (Print), hal. 76-88.

Strauss, J. \& Frost, R. (2014). E-Marketing (7th edition). New Jersey: Pearson Education. 
Suherli, Suryaman, M., Septiaji, A. \& Istiqomah (2017). Bahasa Indonesia: Buku Guru untuk SMA/SMK/MA Kelas X. Jakarta: Pusat Kurikulum dan Perbukuan, Balitbang, Kemendikbud.

Utami, S., \& Murniasih, M. (2016). Peningkatan keterampilan menyusun teks eksplanasi dengan metode peta konsep berbantuan media video peristiwa alam bagi peserta didik kelas VII C SMP Negeri 1 Tawangharjo Kabupaten Grobogan. Jurnal Pendidikan Bahasa dan Sastra Indonesia, 5(2), p-ISSN 2252-6722 e-ISSN 2503-3476, hal. 54-61. 